\section{Emerging Growth Economies in Sub-Saharan Africa}

\author{
Kiertisak Toh ${ }^{1,2}$
}

The American Economist $1-16$

(C)The Author(s) 2016

Reprints and permissions: sagepub.com/journalsPermissions.nav DOI: $|0.1177 / 05694345| 665204 \mid$ aex.sagepub.com

@SAGE

\begin{abstract}
The turning point for the recent growth in Sub-Saharan Africa (SSA) began in the mid-1990s. It, however, has not been uniform across the region. There are countries that have experienced sustained high growth, rivaling those of rapid-growth, emerging economies in Asia. However, more than one third of the countries in Africa still experience low growth, and their economies remain fragile. The article analyzes patterns of long-run, country-level growth. It identifies a group of SSA's emerging economies that are associated with strong growth. The empirical evidence suggests that this group of emerging growth economies is different in terms of economic fundamentals and quality of institutions and governance from the nonemerging slow-growth group.
\end{abstract}

JEL Classifications: O 10, O40, O55

\title{
Keywords
}

growth analytics, growth and development, economic transformation, emerging market economies, Sub-Saharan Africa

\section{Introduction}

For two decades following the oil shocks and worldwide stagflation of the late 1970s, except for a few countries, Sub-Saharan Africa $(\mathrm{SSA})^{1}$ - Africa hereafter-was a region of economic stagnation, poverty, war and conflict, and misgovernance. The average rate of economic growth declined to about $2 \%$. With population growing at $2 \%$ or higher, this amounted to zero or negative per capita growth. It was the long period of stagnation between the mid-1970s and 1990s that Africa became known in the media as the basket case of the world. In 2000, the editors of The Economist magazine ("Hopeless Africa," 2000) described Africa as "The hopeless continent" in its lead editorial.

The usual image of Africa as economically stagnant and heavily dependent on charity and international aid began to turn around in the mid-1990s. For more than a decade since 1995-1996, even with the 2008-2009 global financial crisis and the Great Recession, Africa grew at an average of $5 \%$ per year (World Bank Online) and nearly one quarter of the countries grew at $6 \%$ and higher. Growth did drop in the aftermath of the crisis, but quickly recovered in 2010 and returned to a growth trajectory in the $5 \%$ to $6 \%$ range (International Monetary Fund [IMF], 2015). This strong and persistent growth has attracted the attention of the media and of

'Duke University, Durham, NC, USA

2Radford University, Radford, VA, USA

Corresponding Author:

Kiertisak Toh, Assistant Professor, College of Business and Economics, Radford University, Radford, VA 24I42, USA. Email: ktoh@radford.edu 
development practitioners, researchers, and policy makers. The dire predictions of the "hopeless continent" dependent on aid and charity began to change. By the end of 2011, the lead editorial of The Economist had changed its tone and featured "Africa Rising" on its cover. Many international investors, corporate leaders, and businesses no longer view Africa as the blanket hopeless continent, but as potential investment and business opportunities. This more recent "Africa rising" narrative can be overly ambitious and as misguided as was the dire portrayal of Africa as the hopeless continent. Viewing Africa as a whole can be useful in certain analytical context. But understanding Africa in its parts is critical.

The purpose of this article is twofold. First, it analyzes the pattern of long-run growth based on available 1960-2014 time-series data. Second, as a result of growth dispersion among different countries, the article explores the possibility of categorizing countries into groups: emerging stronggrowth market economies and nonemerging economies in the context of SSA. It tests the hypothesis that there are differences in key economic and institutional variables between the two groups. The next section briefly reviews the literature related to Africa's growth. The "Growth Analytics: Patterns and Stylized Facts" section analyzes the pattern of Africa's growth. The "Categorizing Countries: New Emerging Growth Economies in Africa" section identifies a group of strong-growth emerging economies in Africa and tests the hypothesis of whether the cluster of emerging growth economies is different from the rest in economic fundamentals, in the quality of institutions, and in governance. The "Conclusion" section concludes with some policy implications.

\section{Literature Review of Economic Growth in Africa}

The Africa's growth problem in the literature grew out of the focus of and debate over the role of international aid in the mid-1970s. There are a large number of cross-country econometric studies that have attempted, in varying degrees of sophistication, to find some universal causal mechanisms of growth in developing countries - theoretical and prescriptive universalism. ${ }^{2}$ Africa's growth performance has often been captured by a regional dummy variable in these cross-country growth-regression models. Interest in more accurate and useful descriptions began and has continued to broaden, particularly from private businesses and investors. Academia added their interests to those of the international financial and donor communities, especially as the continent began to be rebranded from the "hopeless continent" to "Africa rising" in the media.

Africa's optimistic outlook in the time of independence in the 1960s dissipated following the sudden oil price shocks of the 1970s; most economies in Africa faltered. Economic decline and stagnation followed throughout the 1980s and the first half of the 1990s. Poor economic management, misgovernance, authoritarian leadership, and violent conflicts and civil wars magnified the effects of external shocks and macroeconomic instability. To respond to the development crisis, lending financial institutions and official donors increased aid flows. This encouraged empirical research largely supported by the international development community. The resulting literature focused broadly on three interrelated areas: understanding the nature of Africa's slow and episodic growth - short spurts of growth and collapses, explaining the causes of slow growth, and suggesting policy and development strategies to address the problem.

In 1981, the World Bank issued an influential report, Accelerated Development in SubSaharan Africa: An Agenda for Action, known as the Berg Report. The report was prepared at the request of the African Governors at the World Bank. It unveiled the World Bank's recommendation for a new strategic approach that emphasized need for policy and structural adjustment. Adjustment lending programs were controversial soon after their conception and implementation. Throughout the 1980s and early 1990s, African governments reluctantly accepted what were known as Structural Adjustment Programs (SAPs) that came with conditions for financial assistance. Many African governments, with limited alternative options, embarked on reforms under the auspices of the World Bank and the IMF. Implementation of SAPs and IMF's Structural 
Adjustment Facility (SAF) programs in practice was poor. Only a small number of governments completed agreed reform measures.

By the early 1990s, it had become evident that SAPs were not working as expected. At the same time, Africa's external debt mounted and became unmanageable. Under political pressures and the successful debt relief movement led by civil society groups and networks of nongovernmental organizations, the World Bank responded by establishing a new financial assistance instrument, the Heavily Indebted Poor Country (HIPC) debt initiative in 1996, followed by Enhanced-HIPC in 1999 (World Bank, 1998, 1999). ${ }^{3}$ In many respects, the HIPC initiative was an outcome of the debate and concerns for growth and development in Africa. The end of the debt crisis, improved economic policies, more democratic and accountable government, changes in relationships with the international communities, and a more favorable external environment began to turn Africa around from stagnation to growth.

Africa's renewed growth first spawned the interest of development financial institutions such as the World Bank, then the media and business community. Reflecting and speculating on the potential positive developments much earlier than the media and the even later arriving corporate sector, the World Bank (2000) issued a report at the turn of the century with the provocative title, Can Africa Claim the 21st Century? The Report challenges African governments to improve economic management, reform economic, and governance institutions; implement microeconomic structural changes to increase competitiveness; diversify their economies; reduce aid dependence; and strengthen partnerships through the creation of a better environment for private and public investment. Africa's continued growth has generated policy-relevant questions: Is Africa finally overcoming the challenge to claim the 21 st century as East and Southeast Asian countries did in the 1970s and 1980s? Is there a turning point from stagnation to growth? How widespread is growth among the 49 countries in SSA? What are the patterns of growth? Can growth be sustained by improvements in economic fundamentals?

\section{Growth Analytics: Patterns and Stylized Facts}

\section{Africa's Growth: 1960-20I 4}

This section analyzes Africa's long-run patterns of growth and discusses some of the stylized facts and features. The analysis is based on time-series data on GDP, per capita GDP (constant 2005 U.S. dollars), and the respective growth rates from 1960 to 2014, for 45 of 49 Sub-Saharan African countries. ${ }^{4}$ In addition, quantitative and qualitative indicators related to policy implementation and the quality of policy, institutions, and business and regulatory environments have also been used. The 55-year period depicts Africa's long-term growth experience: from the immediate postindependence period, the first oil shock, the plunge of commodity prices and deteriorating terms of trade, the decades when African economies collapsed and conflict erupted, the introduction of structural reforms, the recently observed growth recovery and turnaround, and the 2008-2009 global financial and economic crisis. All the data are from the World Bank, World Development Indicators database, unless otherwise noted. ${ }^{5}$

Figures 1 and 2 show the aggregate average annual rate of GDP and GDP per capita growth over a period of 55 years. During the immediate postindependence period between 1961 and the first oil shock in 1973, Africa as a whole experienced strong growth ranging from $6 \%$ to $8 \%$. During this period, Africa's growth was comparable with those of Southeast Asian countries (World Bank, World Development Indicators). The strong performance began to change in the mid-1970s, trending downward with negative or zero growth in some years. As the fitted polynomial trend line in Figure 1 shows, Africa experienced economic stagnation and decline for two decades. With an annual population growth averaging more than $2 \%$ during this period, per capita GDP growth turned negative (Figure 2). 


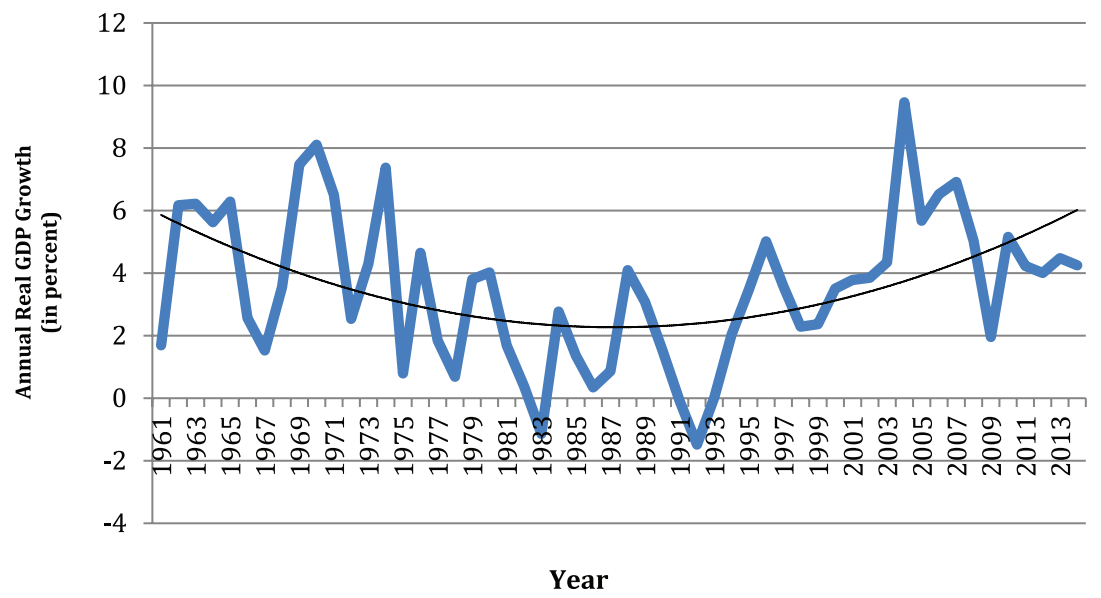

Figure I. Economic growth in Sub-Saharan Africa, 1960-2014.

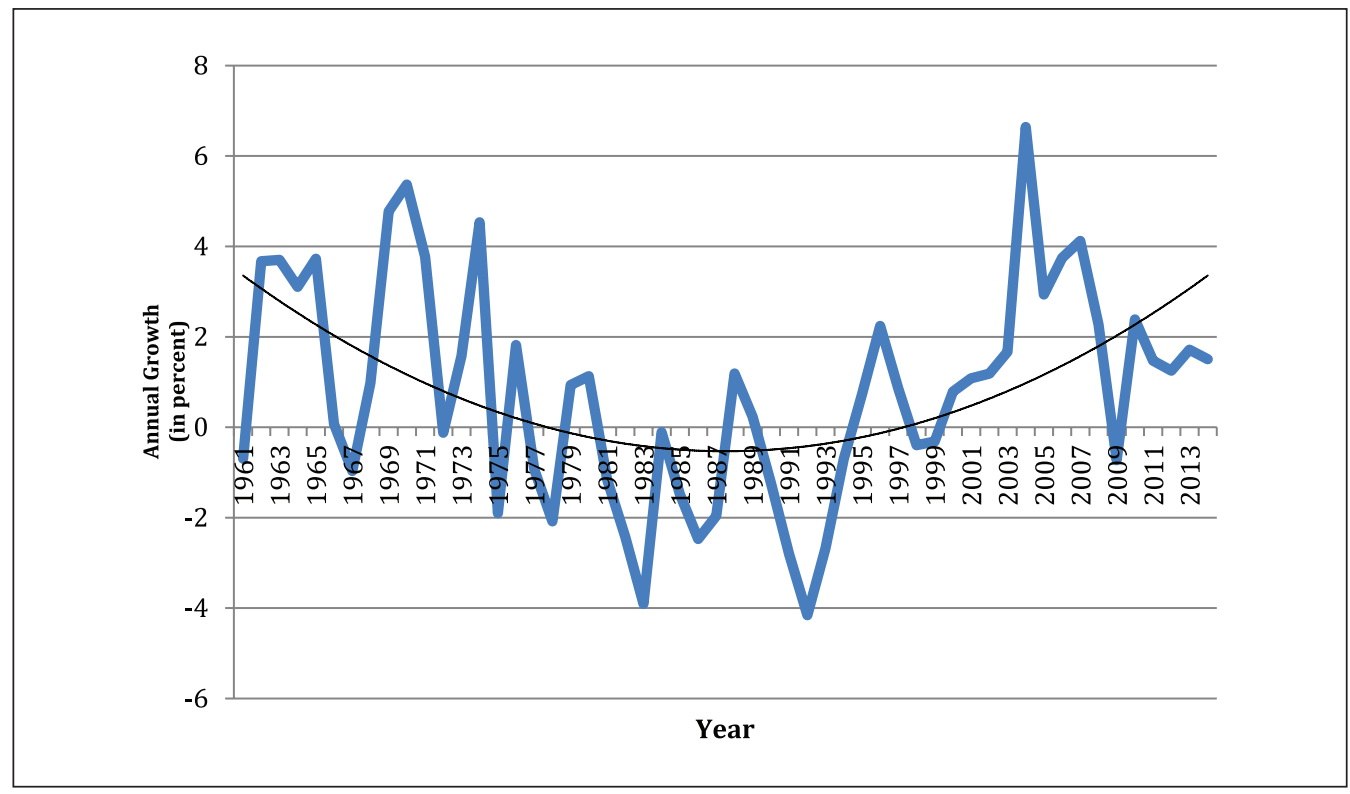

Figure 2. Growth in per capita GDP of Sub-Saharan Africa, 1960-2014.

Consequent to collapsed growth and long-term stagnation, Africa's per capita GDP level declined by more than $20 \%$ between 1974 and 1994 (Figure 3 ). It reversed to the level of immediate postindependence in the early 1960s. It was not until the late 1990s that it began to rise again. Recovery has been persistent and sustained in terms of both aggregate GDP growth and GDP per capita. The mean per capita GDP shows a slow positive long-term trend. Average per capita GDP for Africa as a whole has recovered from the long period of economic stagnation. Figure 3 also shows a trajectory of growth above the long-term exponential trend by the mid-2000s.

Long-run patterns of growth (1961-2014) for Africa as a whole exhibit U-shaped trends in both GDP and per capita GDP with noticeable accelerations and decelerations over shorter 


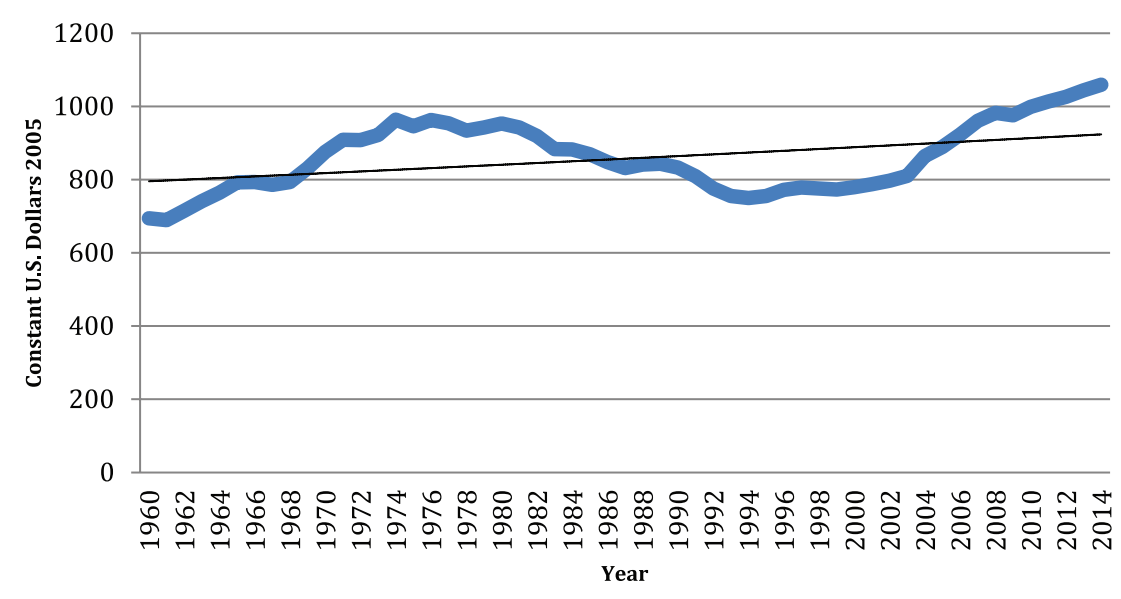

Figure 3. Change in average GDP per capita of Africa, 1960-2014.

Table I. GDP and GDP per Capita Growth for Different Periods in Africa.

\begin{tabular}{lrrr}
\hline Period & $M$ & $S D$ & Coefficient of variation \\
\hline GDP (\%) & & & \\
$1961-1974$ & 4.99 & 2.26 & 0.45 \\
$1975-1984$ & 1.95 & 1.85 & 0.95 \\
$1985-1999$ & 1.90 & 1.78 & 0.94 \\
$2000-2008$ & 5.45 & 1.94 & 0.35 \\
$2000-2014$ & 4.88 & 1.76 & 0.36 \\
Per capita GDP growth (\%) & & & \\
1961-1974 & 2.39 & 2.18 & 0.91 \\
$1975-1984$ & -0.86 & 1.80 & -2.09 \\
$1985-1999$ & -0.86 & 1.76 & -2.03 \\
$2000-2008$ & 2.72 & 1.89 & 0.70 \\
$2000-2014$ & 2.14 & 1.72 & 0.81 \\
\hline
\end{tabular}

Note. In constant 2005 U.S. dollars for the year at the end of each period.

periods. There are, however, significant variations of growth over different shorter periods. Table 1 presents Africa's average annual GDP and per capita GDP growth rates in five different shorter periods: a period of strong growth (1961-1974), a period of decline and stagnation (1975-1984 and 1985-1999), and a period of recovery and accelerated growth (2000-2008 and 2009-2014). In the immediate postindependence period, growth ranged from 5\% to $7 \%$ with the mean of 5\% a year. This strong-growth performance collapsed following the first oil shock in the early 1970 s. For more than two decades (1975-1999), Africa experienced economic decline, episodic growth - a cycle of short-term growth spurts and collapses - and stagnation in general. GDP grew on average less than $2 \%$ a year, which was below population growth. Consequently, per capita growth turned negative. By the early 1990s, the level of per capita income was below the level in the early 1970s. During this long period of economic stagnation, many African countries faced macroeconomic instability, failure of structural reforms, external debt crises, and political and violent conflicts, and some countries faced civil wars. 
Africa's growth patterns began to change by the second half of the 1990s. Table 1 indicated that average annual GDP growth rate for Africa was higher than 5\% between 2000 and 2008 . Africa was adversely affected by the 2008-2010 global financial crisis and recession. However, it recovered relatively quickly after 2009. The average annual growth rate, including the years of the crisis (2000-2014), is only $0.6 \%$ lower than the rate prior to the crisis; it is slightly below 5\%. According to several sources (IMF, World Bank, the African Development Bank, the Organisation for Economic Co-Operation and Development [OECD], and the United Nations Development Programme [UNDP]), Africa's growth outlook is expected to be in the range of $5 \%$ to $6 \%$ in the near term.

Growth volatility is another stylized fact of African economies, particularly evident during the long period of decline and stagnation. The coefficients of variation (Table 1) indicate that the volatility of GDP growth during the decades of stagnation is 3 times the level of the recent growth period, 0.9 versus 0.3 in GDP growth and 2.0 versus 0.8 in per capita GDP growth. Arbache and Page (2007a) argued that Africa's volatile growth reflects a pattern of alternating accelerations and decelerations, rather than random variations of growth around the long-run trend, or the patterns of episodic growths and collapses suggested by Ndulu (2007). According to Arbache and Page (2007b), this pattern of growth affects economic and social outcomes beyond the direct consequences on the rate of growth. The volatility makes it more difficult to sustain growth as it increases uncertainty and risk for both domestic and foreign investment. Arbache, Go, and Page (2008), however, found in their data that there is a "structural break" in the growth series that occurred between 1995 and 1997. They concluded that there is indeed an acceleration of growth in Africa in general. African countries are increasingly avoiding economic collapses. Africa may be at a turning point.

\section{Country-Level Growth Patterns}

The above section analyzes Africa's growth performance as a whole across time. But Africa is vast and diverse. The high degree of growth volatility implies that variations can be both across time and across countries. Disaggregating Africa whole into parts may provide additional insights to certain questions, for example, "Is Africa's growth concentrated in certain types of economies, such as oil-producing or natural-resource-intensive countries, in large or relatively higher income countries?"; "How widespread is the recent growth experience?"; and "How sustainable is current growth?" This section examines country-level growth patterns to attempt to shed light on these questions.

Figure 4 shows four different groups of countries characterized by GDP growth ranges: negative growth, positive but less than $3 \%$, between $3 \%$ and $5 \%$, and growth more than $5 \%$. They are divided into three time periods reflecting the U-shaped trend: immediate postindependence, decline and stagnation, and recovery and accelerated growth period since the turning point. Prior to the oil shock, almost half of the economies in Africa had average annual growth rate higher than $5 \%$. Nearly half of them grew by more than 5\% (e.g., Botswana, Gabon, Côte d'Ivoire, Kenya, Nigeria, South Africa, and Zimbabwe). During the 20-year period following the oil shock, and subsequent structural reforms, misgovernance, and violent conflicts, the number of countries with growth higher than 5\% was cut in half, from 14 to 7 . Seven countries registered negative growth (Angola, Cameroon, Democratic Republic of Congo, Liberia, Mozambique, Nigeria, and Sierra Leon), and one third had less than $2 \%$ growth, including previously higher growth countries, such as Côte d'Ivoire and South Africa.

Since 1995 through 2014, a period that included the 2008-2009 global financial crisis, the number of African economies that achieved a growth rate of higher than 5\% more than doubled, from 7 to 17. Some of them (e.g., Angola, Chad, Equatorial Guinea, Ethiopia, Ghana, Liberia, Sierra Leone, Tanzania, Uganda, and Zambia) have had growth rivaling and even higher than 


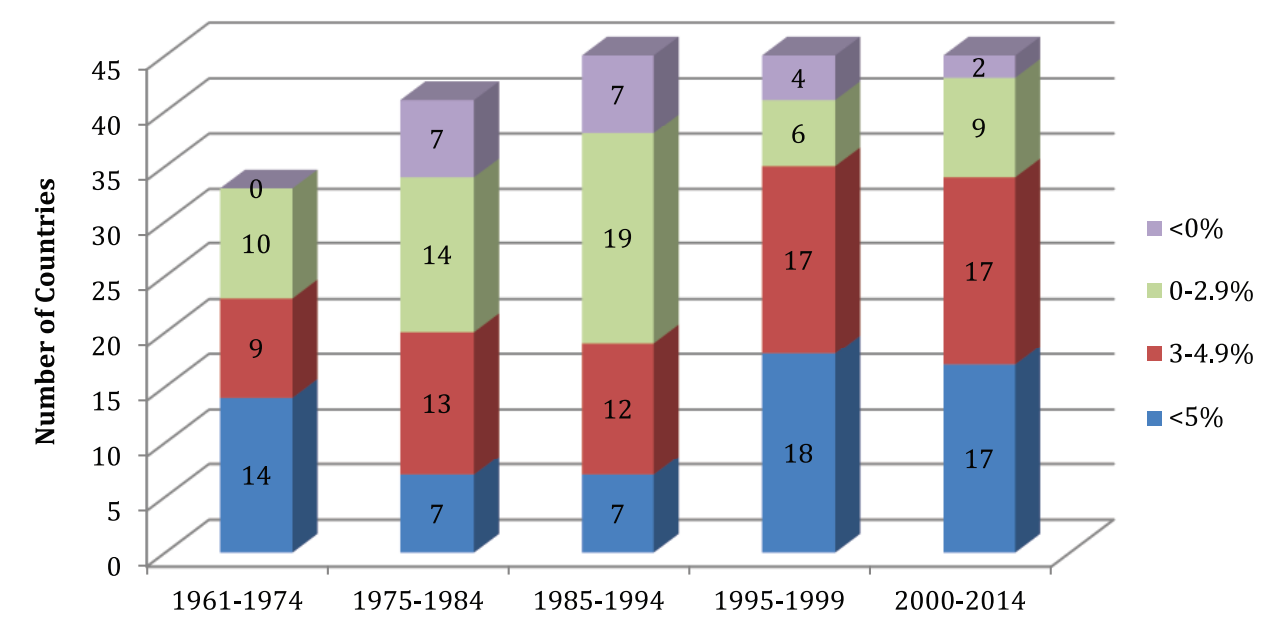

Figure 4. Number of African countries by different GDP growth range, |96|-20|4.

those larger emerging market economies, as presently established. However, a quarter of the region, 11 countries, still grew less than $2 \%$. Others of the remaining countries have had moderate growth of $3 \%$ to $4 \%$. Africa has turned around from stagnation to growth at various speeds. The current growth is widespread but not uniform across all countries. Still, nearly two thirds of the countries experienced growth of more than $4 \%$ a year over the last 15 years.

Table 2 presents descriptive statistics of per capita GDP and its growth for 45 individual African economies. In general, per capita GDP grew modestly between 1995 and 2014.

The median cumulative growth of income between 1995 and 2014 was only 40\%. However, there are 10 countries whose per capita income doubled. Several of them are oil-exporting countries. Angola, Chad, Nigeria, and Equatorial Guinea grew by more than 16 times. There are also low-income, nonoil-exporting, and postconflict countries whose average income has doubled, such as Ethiopia, Mozambique, and Liberia (more than quintuple). But the growth is not uniform across the region. There are also countries whose average per capita income is actually lower in 2014 than in 1995. This includes Burundi, Central African Republic, Eritrea, Zimbabwe, and Gabon (also an oil-exporting country).

The country-level variations of per capita income are relatively low. The coefficient of variation ranges from a high of 0.29 to 0.22 for a few oil-exporting countries like Angola, Equatorial Guinea, and Nigeria to the relatively low coefficients of variation in most countries. The median coefficient is $0.13 .{ }^{6}$ On the contrary, the growth rate of per capita income is highly volatile. Its coefficient of variation ranges from -42.1 to the high of 19.4 for Madagascar and The Gambia. The median coefficient is 1.1 , nearly 10 times of that of per capita income. Although Africa's cumulative per capita income at an aggregate level grew by a mere $40 \%$ over a 20 -year period, at the country level there are 10 countries whose per capita income has more than doubled and another eight that has nearly doubled.

\section{Categorizing Countries: New Emerging Growth Economies in Africa}

In the literature of the late 1990s and early 2000s, many economists raised questions about how widespread growth was in Africa and whether it could be sustained. Collier and Gunning (1999a, 1999b) and Kenny and Williams (2001) provided a good literature review and summary of many 


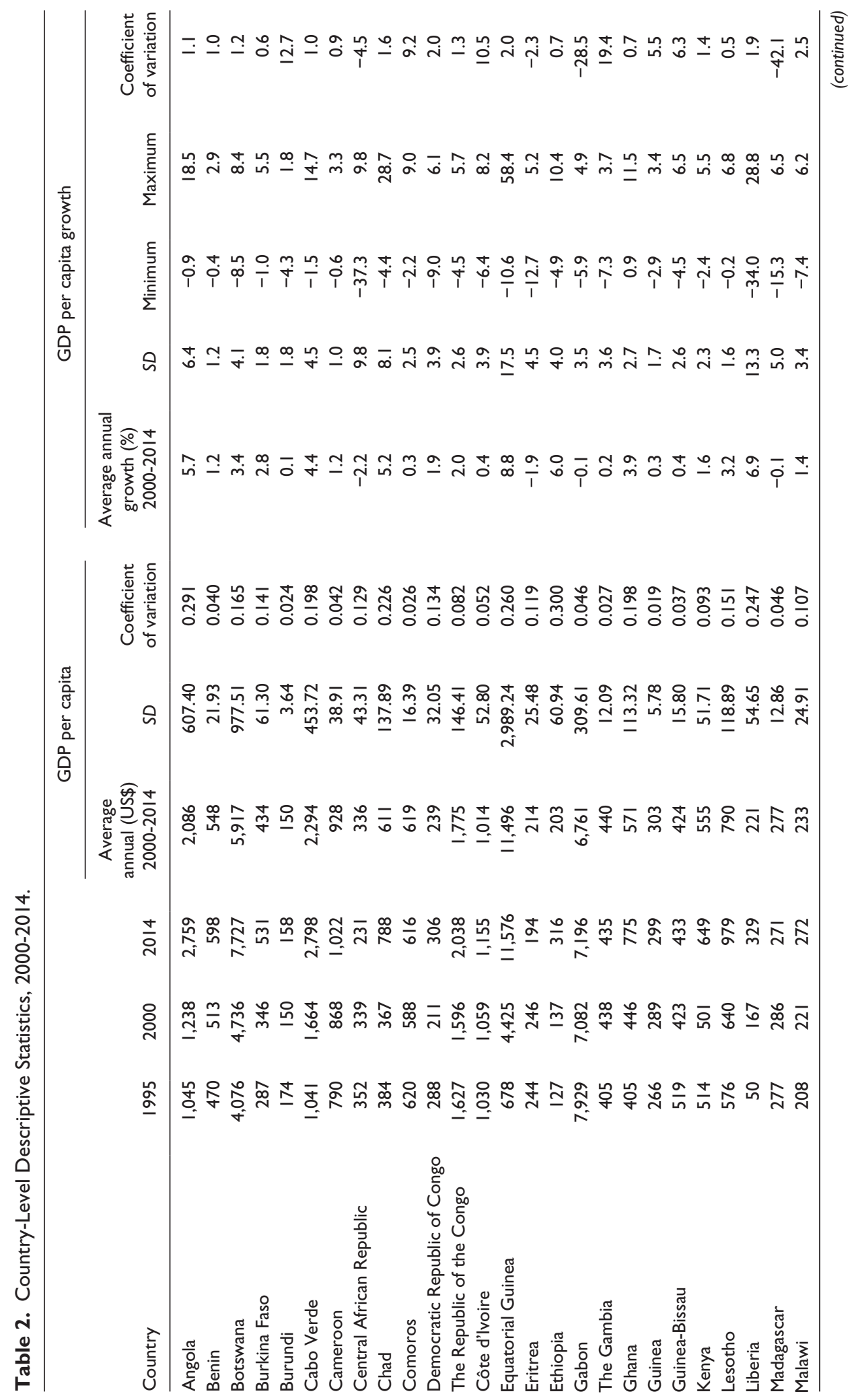




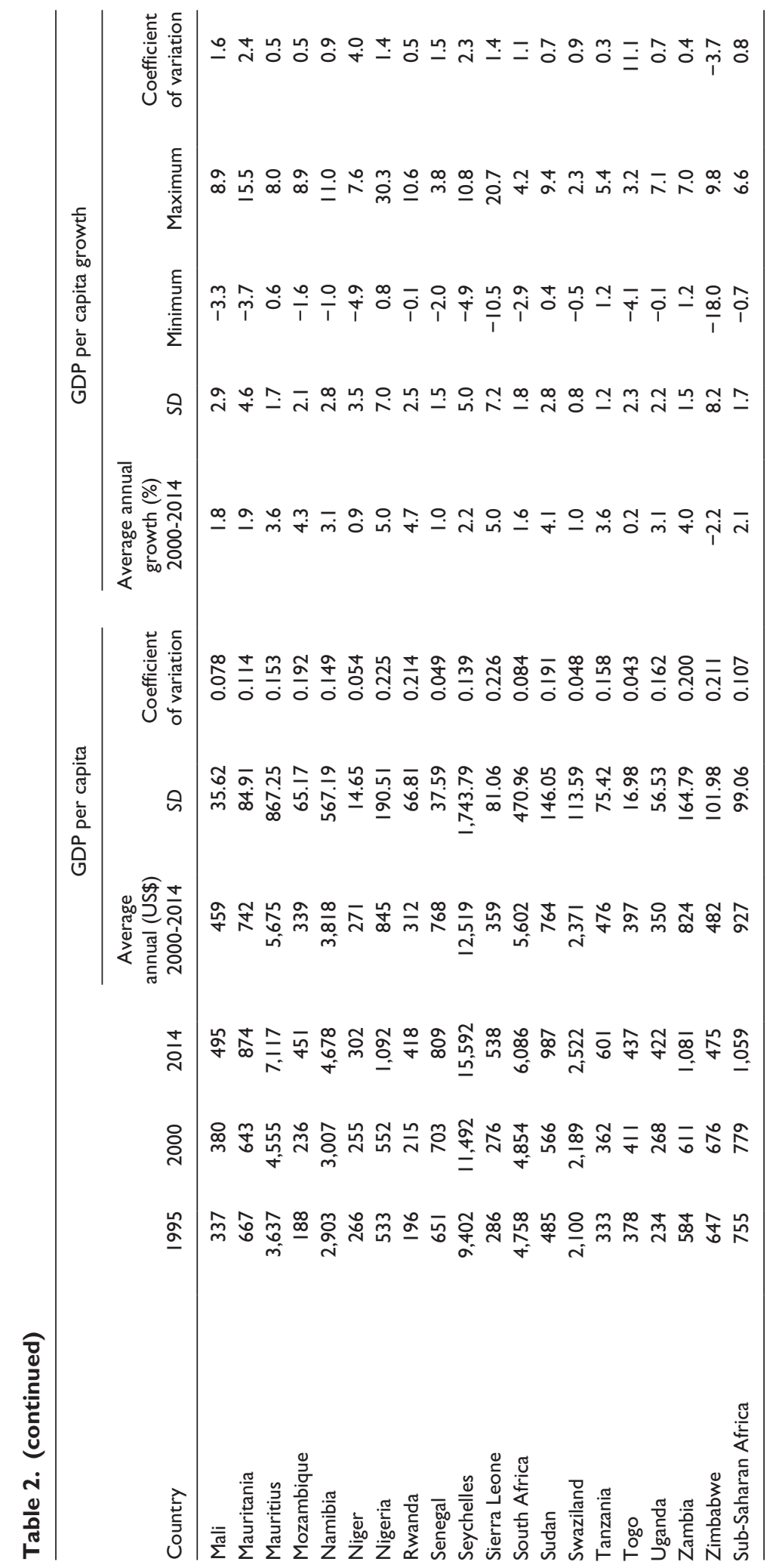


Table 3. How Widespread Is Africa's Growth?

\begin{tabular}{|c|c|c|c|c|c|c|c|}
\hline \multicolumn{4}{|l|}{ Growth $>4 \%$} & \multicolumn{4}{|c|}{ Growth $<4 \%$} \\
\hline $\begin{array}{l}\text { Nonoil } \\
\text { exporting }\end{array}$ & $\begin{array}{c}\text { Oil } \\
\text { exporting }\end{array}$ & Postconflict & Landlocked & $\begin{array}{l}\text { Nonoil } \\
\text { exporting }\end{array}$ & $\begin{array}{c}\text { Oil } \\
\text { exporting }\end{array}$ & Postconflict & Landlocked \\
\hline Benin & Angola & $\begin{array}{l}\text { Congo, } \\
\text { Democratic }\end{array}$ & Botswana & Comoros & Cameroon & Burundi & $\begin{array}{l}\text { Central } \\
\text { African } \\
\text { Republic }\end{array}$ \\
\hline Cabo Verde & Chad & Liberia & $\begin{array}{l}\text { Burkina } \\
\text { Faso }\end{array}$ & Eritrea & Gabon & $\begin{array}{l}\text { Côte } \\
\text { d'lvoire }\end{array}$ & Swaziland \\
\hline Ghana & $\begin{array}{l}\text { Congo, } \\
\text { Republic }\end{array}$ & Sierra Leone & Ethiopia & The Gambia & & & Zimbabwe \\
\hline Kenya & $\begin{array}{c}\text { Equatorial } \\
\text { Guinea }\end{array}$ & & Lesotho & Guinea-Bissau & & & \\
\hline Mauritius & Mauritania & & Malawi & Guinea & & & \\
\hline Mozambique & Nigeria & & Mali & Madagascar & & & \\
\hline Namibia & Sudan & & Niger & Senegal & & & \\
\hline \multirow[t]{3}{*}{ Tanzania } & & & Rwanda & Seychelles & & & \\
\hline & & & Uganda & South Africa & & & \\
\hline & & & Zambia & Togo & & & \\
\hline
\end{tabular}

growth-regression empirical studies. Some observed that commodity booms and favorable terms of trade in the 1990s were factors driving Africa's growth, or the fact that Africa had been in decline and stagnation for a long time contributed to a more speedy, catch-up growth once recovery took hold. Others suggested what Collier and Gunning called "destiny factors," such as geography like being landlocked countries or tropical climates and diseases (Sachs \& Warner, 1997), and fractious ethnic division (Easterly, 1997).

So, how widespread is Africa's recent growth? To answer this question, a matrix of two by four is constructed as shown in Table 3. Countries are separated into two groups: strong growth ( $4 \%$ or higher) and weak growth (less than $4 \%$ ). In each category of growth, the countries' economies are further divided into four subgroups: nonoil-exporting, oil-exporting, landlocked, and postconflict countries. Each country is designated by its growth performance and categorized by one of the four possible types of economies. ${ }^{7}$ Based on growth data between 2000 and 2014, Table 3 shows that 28 of the 45 countries have a growth rate of $4 \%$ or higher. They comprise all four types of economies. Although seven of the nine strong-growth economies are oil exporting, they are not predominant. Eight nonoil-exporting and 10 landlocked countries also have strong growth. Being a landlocked country does not seem to destine a country to low growth. Landlocked countries, such as Ethiopia, Rwanda, Uganda, and Zambia, have registered long-term growth ranging between $6 \%$ and $8 \%$. The strong-growth group also includes three recently postconflict countries: Liberia, Sierra Leone, and Democratic Republic of Congo. The evidence suggests that even low-income, fragile, and conflict-affected countries can grow. Countries can overcome the "destiny factors," especially those determined by natural resources and geography.

Although Africa's growth is widespread across different types of economies, it is volatile and not uniform. More than one third of the countries in Africa, 17 of them, still experience low growth (Table 3). Are there differences between higher growth economies and lower growth economies in terms of economic fundamentals and other economic performance variables, such as the quality of policies and institutions? Can African countries be meaningfully categorized into country groups or clusters? Answers to these questions may shed light on whether growth is robust and sustainable. 
By the early 2000s, Africa's renewed growth began to receive attention in the "Africa rising" literature. A number of international investors, corporate leaders, commentaries, and business and development books discussed potential opportunities in Africa. McKinsey Global Institute (2010) published an optimistic review of the continent's economic outlook with the catchy title of Lions on the Move: The Progress and Potential of African Economies. Others suggested emerging "frontier markets," a "second generation" of emerging market economies, and an emerging Africa (Berman, 2013; Mahajan, 2009; Miguel, 2009; Nellor, 2008; Radelet, 2010).

The idea of Africa's emerging economies is an outgrowth of the concept of emerging markets. Developed and developing countries can be distinguished in terms of income and the level and sophistication of markets, among other indicators. A conventional approach adopted by international financial institutions, such as the World Bank and the IMF, is to classify developing economies based on income level. It serves the purpose of lending operations for the World Bank and the IMF because the eligibility for different types of concessional loans the institutions offer is generally determined by the country's income level. Country typology is also useful for analytical work and for forecasting purposes. Being able to differentiate different types of economies can be important for business and potential foreign investors. Arguably, the emergence of new markets can affect investment decisions, particularly in the context of low- and middleincome developing countries. In 1980, Antoine van Agtmael of the International Financial Corporation (IFC), the private investment arm of the World Bank Group established to support businesses and private enterprises in developing countries, coined the term "emerging markets" to refer to developing countries with stock markets that were beginning to have features of the mature financial and stock markets in developed, industrial countries.

Financial markets in particular have made use of the concept of emerging markets. Several emerging market indices and investment funds have been established (see, for example, Master Card Worldwide Centers of Commerce: Emerging Markets Index, 2008; Emerging and GrowthLeading Economies; FTSE Global Emerging Markets Index (2015); and the IMF list of emerging market economies). Standard \& Poor's that took over the emerging market financial indices from the IFC in 2000 compiled a list of countries called "frontier markets" to describe those markets that are less liquid than those in the emerging markets. In the context of SSA, South Africa is the only country included in all emerging market groups because it meets the criteria of financial market development. Kenya, Nigeria, and Senegal are included in some groups. Emerging markets, later also called emerging (market) economies, are loosely defined as a group of rapidly growing developing countries that are reasonably integrated into the global economy. In general, four characteristics have been adopted as defining features of emerging economies: low- to middle-income countries with high growth, an emerging financial or equity capital market, reasonable integration to the global economy via trade and investment, and rule-based governance and accountability.

During the two decades of economic stagnation, emerging markets as a taxonomical in most African countries received relatively little attention by business leaders and investors. Today, Africa in a broad sense has turned around. It has a new economic landscape with accelerated growth, and its volatility in recent years implies more opportunities, higher risks, and higher returns for investors. It has shown resiliency and a continuing growth trajectory of $5 \%$ to $6 \%$ (African Development Bank, 2015; IMF, 2015) following the global financial and economic crises suggesting that growth can persist. However, Africa is diverse and its diversity is increasing; varying growth performance across countries is also a notable characteristic. Potentially, this can lead to the formation of country groups or clusters based on economic outcomes, for example, high- and low-growth economies, quality of institutions and governance, across the conventional classification by income level or geography. The concept of emerging market economies offers one such grouping. ${ }^{8}$ 
However, the idea of defining an emerging market economy predominantly by a country's financial or capital markets is narrow and leaves out other key features that characterize emerging economies. Kehl (2007) discussed the inadequacy and inaccuracy of the conception of emerging markets that rely mainly on the existence of institutions to support a capital market or a stock or portfolio market. She argued that this has disproportionately left out many African countries and created a negative impact on Africa. Foreign investment can be important for domestic growth, and being considered an emerging market adds value to any "county brand" attempting to attract business and investment. Relying on survey evidence by the United Nations about the motivations, operations, and perceptions of business leaders and investors, Kehl applied a cross-sectional time-series analysis using 10 political institutions and economic indicators. She identified a list of 19 emerging and upcoming emerging markets in Africa. Nellor (2008) has also observed that a number of Sub-Saharan countries were beginning to attract investors to their financial markets. Based on the analysis of a number of economic and political variables, Radelet (2010) similarly concluded that a number of African countries exhibit the characteristics of emerging economies. He identified 17 African countries as emerging economies and another six as "threshold" emerging economies. Radelet's list excluded nine oil-exporting countries; many of them could be considered as emerging economies. The descriptive statistics available to Radelet at the time were from the mid-2000s. The data Kehl used for her econometric analysis were from the late 1990 s and early 2000s.

The concept of emerging market economies can be seen as an approach to categorize economies into separate groups or clusters based on some objective criteria. Applying the broader concept of emerging markets to more recent data (2000-2014) and using average annual growth rates between 2000 and 2014 as an overall objective and proxy measure of economic outcome, a list of 28 strong-growth countries achieving a growth rate of $4 \%$ or higher are considered emerging economies (Table 3 ). ${ }^{9}$ They are separated from the nonemerging economies by growth performance. An annual $4 \%$ growth in the context of Africa is about $2 \%$ growth per capita. It is a moderate rate of per capita growth. This is the rate that has conventionally been a benchmark and a common standard indicating relatively good performance when sustained over time. It means a doubling of income in 36 years, fewer than two generations. The emerging market group identified in this article turns out to be identical to Radelet's list if oil-exporting countries and those Radelet considered threshold emerging economies, except Senegal, are included. This grouping is very similar to Kehl's with the exception that Gabon, The Gambia, Madagascar, and Senegal are on her "upcoming emerging" list but are not on the emerging market group in this article.

If growth is robust, countries with strong growth (emerging economies) should have different - stronger - economic performance as measured by key economic fundamentals and policies and institutions that support growth than low-growth, nonemerging economies. One can infer that growth is associated with improved economic fundamentals and sound policies and institutions rather than just the luck of favorable commodity prices and more international aid. Table 4 compares the means of selected economic variables between two groups of economies. One group comprises 29 growth emerging economies; the other comprises 16 nonemerging economies (Table 3). Eighteen variables are chosen. They represent major indicators that business leaders and investors would likely use, among other things, to guide decisions about whether to invest in a particular country. These performance or outcome indicators capture economic fundamentals, macroeconomic policy variables, the extent of policy implementation, the quality of institutional support for reforms, and the control of corruption and good governance. The data are from the World Bank, World Development Indicator data set. The indicators of the quality of policy execution, institutions, and governance rely on the World Bank's Country Policy and Institution Assessment, which uses a scale of 1 to 6 , with 1 scoring the lowest quality and 6 the highest. 
Table 4. Comparison of Means of Selected Economic Variables: Emerging and Nonemerging Economies, 2000-20I4.

\begin{tabular}{|c|c|c|c|c|c|c|}
\hline \multirow[b]{2}{*}{ Indicators } & \multicolumn{3}{|c|}{ All countries } & \multicolumn{3}{|c|}{ Nonoil exporting } \\
\hline & $\begin{array}{l}\text { Emerging } \\
\text { economies }\end{array}$ & $\begin{array}{l}\text { Nonemerging } \\
\text { economies }\end{array}$ & $\begin{array}{c}t \\
\text { test }\end{array}$ & $\begin{array}{l}\text { Emerging } \\
\text { economies }\end{array}$ & $\begin{array}{l}\text { Nonemerging } \\
\text { economies }\end{array}$ & $\begin{array}{c}t \\
\text { test }\end{array}$ \\
\hline Savings (\% GDP) & 19.7 & 9.3 & $*$ & 19.7 & 9.3 & $*$ \\
\hline Investment (\% GDP) & 15.7 & 11.1 & $*$ & 15.0 & 10.1 & $*$ \\
\hline ODA received (\% GDI) & 11.2 & 9.2 & & 13.3 & 10.2 & \\
\hline $\begin{array}{l}\text { Foreign investment, net flow } \\
\text { (\% GDP) }\end{array}$ & 6.6 & 3.2 & $*$ & 5.7 & 3.5 & \\
\hline Trade (\% GDP) & 80.4 & 78.9 & & 72.6 & 80.9 & \\
\hline \multicolumn{7}{|l|}{ Macroeconomic management } \\
\hline Inflation & 11.4 & 5.7 & & 10.4 & 6.3 & $*$ \\
\hline Government consumption & 15.2 & 15.8 & & 15.9 & 16.4 & \\
\hline Debt service (\% GNI) & 3.0 & 3.0 & & 2.8 & 2.8 & \\
\hline $\begin{array}{l}\text { Current account balance } \\
\text { (\% GDP) }\end{array}$ & -7.4 & -4.9 & & -8.5 & -7.9 & \\
\hline \multicolumn{7}{|c|}{ Policies, institutions, and governance (CPIA scale; $1+=$ low and $6=$ high) } \\
\hline Economic management & 3.8 & 3.1 & $*$ & 4.0 & 3.0 & $*$ \\
\hline Fiscal policy & 3.6 & 2.8 & $*$ & 3.8 & 2.7 & $*$ \\
\hline $\begin{array}{l}\text { Quality of budgetary and } \\
\text { financial management }\end{array}$ & 3.3 & 2.6 & $*$ & 3.1 & 2.7 & $*$ \\
\hline Debt management & 3.6 & 2.4 & * & 3.8 & 2.4 & $*$ \\
\hline Financial sector structure & 3.1 & 2.6 & $*$ & 3.2 & 2.6 & $*$ \\
\hline $\begin{array}{l}\text { Business, regulatory } \\
\text { environment }\end{array}$ & 3.2 & 2.8 & $*$ & 3.6 & 2.5 & $*$ \\
\hline Structural policies & 3.4 & 3.0 & $*$ & 3.5 & 2.9 & $*$ \\
\hline $\begin{array}{l}\text { Property rights and rule- } \\
\text { based governance }\end{array}$ & 2.9 & 2.5 & $*$ & 3.1 & 2.4 & $*$ \\
\hline $\begin{array}{l}\text { Control of corruption, } \\
\text { transparency, and } \\
\text { accountability }\end{array}$ & 2.9 & 2.2 & $*$ & 3.1 & 2.2 & $*$ \\
\hline
\end{tabular}

Note. ODA = official development assistance; GDI = gross domestic investment; GNI = gross national income; CPIA = Country Policy and Institutional Assessment.

*Statistically significant at the $5 \%$ level.

First, the study compares the difference in the means of the selected variables between the group of 29 emerging growth economies, including seven oil-exporting economies, and the group of 16 nonemerging growth economies. The empirical results are shown on the second and third columns of Table 4. The statistical $t$ test shows that the means of the two groups in savings, domestic investment, and foreign direct investment are different and significant at $5 \%$ level. Similar results hold for all the variables measuring quality of policy implementation, institutions, and governance. However, the $t$ test also indicates that there is no difference between the means of the two groups in terms of inflation, government consumption, debt, and current account balance.

Second, to test the extent to which oil-rich countries affect the results, the nine oil-exporting economies, seven in the emerging growth group and two from the nonemerging growth group, are dropped from the sample. The $t$ test shows that there are differences in the means in savings and domestic investment (as in the case of all countries) but no differences in foreign direct investment. The means of the inflation variable between the two groups are different and statistically significant once the oil-rich countries are dropped. 
The results in terms of quality of policies, institution, and governance are the same whether or not oil-exporting economies are included in the sample. Except for the foreign direct investment and inflation variables, the selected performance variables are not sensitive to whether oil-rich countries are included.

The statistical inference from the $t$ test is quite limited. The findings do not imply causality. They simply suggest that Africa's growth economies as a group are statistically different and associated with better economic fundamentals and quality of certain policies, institutions, and governance.

\section{Conclusion}

In the literature on growth empirics, there are many cross-country econometric studies that attempt to find some universal causal mechanisms that explain why some countries grow faster than the others. In this type of global studies, Africa is typically included in a reduced-form, growth regression by a regional dummy variable. Two general distinctions in the causes of slow growth for Africa emerged in the literature: "destiny factors," particularly geography and ethnic division, and those factors that are policy and institutions dependent, such as sound macroeconomic policies, structural reforms, and good governance.

Is slow growth intrinsic in Africa? Based on the empirical findings in this article (Table 3), which benefit from a more recent and longer data set since the turnaround in the mid-1990s, the answer is negative. Africa's growth has been widespread. Many countries have managed to achieve strong growth despite their geography_-being landlocked or tropical—and ethnic divisions. These factors do not appear to be intrinsically binding constraints. A majority of the growth economies and some of the rapidly growing ones in the past 15 years, such as Botswana, Ethiopia, Rwanda, and Uganda, are landlocked countries. In the much longer term, geographic locations that are vulnerable to adverse impacts of climate change can potentially be a growthlimiting factor. Not being well endowed with oil or other natural resources does not inevitably slow down growth. A majority of the growth economies are not natural-resource- or oil-rich countries. It is equally evident that natural resources are not intrinsically a curse; $15 \%$ of the growth economies in this study are oil-exporting countries.

If destiny or intrinsic factors are not good explanations for slow growth and stagnation, policyand institution-dependent factors are. As a group, growth economies are statistically different from slow-growth and stagnant economies in terms of economic fundamentals, policies, institutions, and governance. The differences are especially distinct and significant in the areas of policy management and implementation and quality of institutions and governance. These variables are measured by qualitative or categorical measurements that are not easily integrated into global growth-regression analytics. It should also be pointed out that statistical inference by comparison of the means of two groups of countries in terms of different variables does not imply causality. The findings should be interpreted differently than as determinants of growth as in the case of growth-regression models. The findings simply suggest that growth economies as a group are statistically different and associated with better economic fundamentals, certain policies, and better quality of institutions and governance.

The "Africa rising" literature, to a large extent, came from the corporate sector's interest in Africa, and examples tend to be country or area specific unlike the literature on cross-country econometric studies. The two sources can be complementary. Although Africa's turning point has occurred, Africa's growth has not been uniform. It is volatile and uneven. Thus, for business and investors, the concept of emerging market or growth economies can be useful. The designation signals to business leaders and investors that the challenges of new markets hold promise but also higher risks and returns. Moreover, disaggregated, country-specific context provides an opportunity to erode the long-standing reference to "Africa as a country" that affected by the 
news media and so affecting public perception to the frustration of many leaders and ordinary citizens of Africa. Their economies are misleadingly lumped together when Africa is treated as a single analytical unit and overgeneralized. The analytical practice of treating "Africa as a country" can be misleading and inaccurate.

Is Africa's growth robust? Can it be sustained? These are more difficult questions to answer. The association between strong growth and the quality of policies, institutions, and governance over a 15-year period (Table 4) seems to lend support to the view that growth in Africa's emerging economies has been robust. Will it continue to be resilient and different from the past experience of episodic growths and collapses? As to the second question, economic development theory suggests that to be sustained, growth has to be accompanied by structural transformation driven by productivity gains. To date, little of the transformation process suggested by textbook explanations is evident. The jury is still out, and it is a challenge for continuing research and for Africa's business and political leaders.

\section{Declaration of Conflicting Interests}

The author(s) declared no potential conflicts of interest with respect to the research, authorship, and/or publication of this article.

\section{Funding}

The author(s) received no financial support for the research, authorship, and/or publication of this article.

\section{Notes}

1. Sub-Saharan Africa comprises 49 of the 54 countries in Africa — excluding North African countries of Algeria, Egypt, Libya, Morocco, and Tunisia.

2. The results, however, were disappointing in that no model has proven robust to trial by repeated regression (Kenny \& Williams, 2001).

3. Of the total 40 countries under HIPC (Heavily Indebted Poor Country), 33 were from Africa. The HIPC and debt relief initiative was successful in reducing debt overhangs of many heavily indebted countries (World Bank, 2011).

4. Djibouti, São Tomé and Príncipe, Somalia, and South Sudan are not included in the sample for lack of data.

5. Because the primary interest here is in examining the representative country, unweighted country-level data are used in the aggregate analysis.

6. This is consistent with the overall slow, moderate change in per capita income at the aggregate level across time (Figure 3).

7. Countries can fall into one or more types, for example, Rwanda is a strong-growth, nonoil-exporting, landlocked, and postconflict country. To simplify in cases such as this, the country is arbitrarily placed into only one of the four types.

8. For other suggested approaches, see, for example, Nielsen (2011) and Vazquez and Sumner (2012).

9. There is one exception. South Africa, with a growth rate of $3.2 \%$, is added to the group of emerging economies because it has already been universally considered an emerging market economy.

\section{References}

Africa rising. (2011, December 3). The Economist. Retrieved from http://www.economist.com/ node $/ 21541015$

African Development Bank. (2015). African economic outlook, 2015. Tunis, Tunisia: Author.

Arbache, J., Go, D. S., \& Page, J. (2008). Is Africa's economy at a turning point? (Policy Research Working Paper No. 4519). Washington, DC: World Bank.

Arbache, J., \& Page, J. (2007a). More growth or fewer collapse? A new look at long run growth in SubSaharan Africa (Policy Research Working Paper No. 4384). Washington, DC: World Bank.

Arbache, J., \& Page, J. (2007b). Patterns of long term growth in Sub-Saharan Africa (Policy Research Working Paper No. 4398). Washington, DC: World Bank. 
Berman, J. (2013). Success in Africa: CEO insights from a continent on the rise. Bibliomotion. Available from http://www.bibliomotion.com

Collier, P., \& Gunning, J. W. (1999a). Explaining African economic performance. Journal of Economic Literature, 37, 64-111.

Collier, P., \& Gunning, J. W. (1999b). Why has Africa grown slowly? The Journal of Economic Perspectives, 13(3), 3-22.

Easterly, W. R. (1997). Africa's growth tragedy: Policies and ethnic division. The Quarterly Journal of Economics, 112, 1203-1250.

FTSE Global Emerging Markets Index. (2015). FTSE annual country classification review. Retrieved from http://www.ftse.com/products/downloads/FTSE-Country-Classification-Update_latest.pdf

Hopeless Africa. (2000, May 11). The Economist. Retrieved from http://www.economist.com/node/333429

International Monetary Fund. (2015). Regional economic outlook: Sub-Saharan Africa. Washington, DC: Author.

Kehl, J. R. (2007). Emerging markets in Africa. African Journal of Political Science and International Relations, 1(1), 1-8.

Kenny, C., \& Williams, D. (2001). What do we know about economic growth? Or, why don't we know very much? World Development, 29, 1-22.

Mahajan, V. (2009). Africa rising. Upper Saddle River, NJ: Wharton School Publishing.

Master Card Worldwide Centers of Commerce: Emerging Markets Index. (2008). Retrieved from http:// www.mastercard.com/us/company/en/insights/pdfs/2008/MCWW_EMI-Report_2008.pdf

McKinsey Global Institute. (2010). Lions on the move: The progress and potential of African economies. Washington, DC: Author.

Miguel, E. (2009). Africa's turn? Cambridge, MA: MIT Press.

Ndulu, B. J. (2007). Challenges of African growth: Opportunities, constraints, and strategic directions. Washington, DC: World Bank.

Nellor, D. (2008, September). The rise of Africa's "frontier" markets. Finance \& Development, 45(3), 30-33.

Nielsen, L. (2011). Classifications of countries based on their level of development: How it is done and how it could be done (IMF Working Paper No. wp/11/31). Washington, DC: International Monetary Fund.

Radelet, S. (2010). Emerging Africa. Washington, DC: Center for Global Development.

Sachs, J., \& Warner, A. (1997). Natural resource abundance and economic growth (Development Discussion Paper No. 517a). Cambridge, MA: Harvard Institute for International Development.

Vazquez, S. T., \& Sumner, A. (2012). Beyond low and middle income countries: What if there were five clusters of developing countries? (IDS Working Paper, Vol. 2012(404)). London, England: Institute of Development Studies.

World Bank. (1981). Accelerated development in Sub-Saharan Africa: An agenda for action. Washington, DC: Author.

World Bank. (1998). The Initiative for Heavily Indebted Poor Countries: Review and outlook (Report No. DC/98-15). Retrieved from http://siteresources.worldbank.org/INTDEBTDEPT/ PolicyPapers/20253115/1998-HIPC-ReviewOutlook.pdf

World Bank. (1999). Modifications of the Heavily Indebted Poor Countries (HIPC) Initiative. Retrieved from http://siteresources.worldbank.org/INTDEBTDEPT/PolicyPapers/20253088/1999-Sept17Modification-5.pdf

World Bank. (2000). Can Africa claim the 21st century? Washington, DC: Author.

World Bank. (2011). Heavily Indebted Poor Countries (HIPC) Initiative and Multilateral Debt Relief Initiative (MDRI)-Status of implementation and proposal for the future of the HIPC Initiative. Retrieved from http://siteresources.worldbank.org/INTDEBTDEPT/ProgressReports/23063134/HIPC_ MDRI_StatusOfImplementation2011.pdf

\section{Author Biography}

Kiertisak Toh is a former senior executive, presidentially commissioned Minister Counselor in the U.S. Senior Foreign Service, senior fellow with Duke Center for International Development, Duke University (North Carolina, USA), and special purpose faculty of economics at Radford University (Virginia, USA). 